\title{
Prospects of complete feed system in ruminant feeding: A review
}

\author{
Yasir Afzal Beigh, Abdul Majeed Ganai and Haidar Ali Ahmad
}

Division of Animal Nutrition, Faculty of Veterinary Sciences and Animal Husbandry, Sher-e-Kashmir University of Agricultural Sciences \& Technology of Kashmir, Shuhama - 190 006, Srinagar, Jammu and Kashmir, India.

Corresponding author: Yasir Afzal Beigh, e-mail: vetyasir1@gmail.com,

Co-authors: AMG: ganaimajeed1@gmail.com, HAA: haidaraa74@gmail.com

Received: 01-12-2016, Accepted: 25-02-2017, Published online: 21-04-2017

doi: 10.14202/vetworld.2017.424-437 How to cite this article: Beigh YA, Ganai AM, Ahmad HA (2017) Prospects of complete feed system in ruminant feeding: A review, Veterinary World, 10(4): 424-437.

\begin{abstract}
Effective utilization of available feed resources is the key for economical livestock rearing. Complete feed system is one of the latest developments to exploit the potential of animal feed resources in the best possible way. The complete feed is a quantitative mixture of all dietary ingredients, blended thoroughly to prevent separation and selection, fed as a sole source of nutrients except water and is formulated in a desired proportion to meet the specific nutrient requirements. The concentrate and roughage levels may vary according to the nutrient requirement of ruminants for different production purposes. The complete feed with the use of fibrous crop residue is a noble way to increase the voluntary feed intake and thus animal's production performance. In this system of feeding, the ruminant animals have continuous free choice availability of uniform feed mixture, resulting in more uniform load on the rumen and less fluctuation in release of ammonia which supports more efficient utilization of ruminal non-protein nitrogen. Feeding complete diet stabilizes ruminal fermentation, thereby improves nutrient utilization. This feeding system allows expanded use of agro-industrial byproducts, crop residues and nonconventional feeds in ruminant ration for maximizing production and minimizing feeding cost, thus being increasingly appreciated. However, to extend the concept extensively to the field and make this technology successful and viable for farmers, more efforts are needed to be taken.
\end{abstract}

Keywords: benefits, complete feed, concept, feeding, ruminants

\section{Introduction}

Livestock forms an integral part of agriculture sector and encompass a great impact on the national economy; however, nutritional inadequacy for livestock is at currently referred one of the most burning global problems of agricultural countries. Due to higher population growth rate and its consequential pressure, available land for forage production is declining day by day. This wicked scenario of quality feed resource availability has virtually eclipsed the genetic worth of animals. In such circumstances, the extensive use of crop residues in livestock feeding seems to be indispensable to meet the nutritional needs of livestock; however, the major constraint in the utilization of these crop residues is high cellulosic contents and poor nutritive value that even cannot support the maintenance nutrient requirement of the animals. Hence, efforts are being directed toward assisting the animals to utilize these low-grade feedstuffs more efficiently as effective utilization of available feed resources is the key to enhance livestock productivity economically. Efficient utilization of crop residues available locally in appreciable quantum seems to be accomplished by the application of feed technology

Copyright: Beigh, et al. Open Access. This article is distributed under the terms of the Creative Commons Attribution 4.0 International License (http://creativecommons.org/licenses/by/4.0/), which permits unrestricted use, distribution, and reproduction in any medium, provided you give appropriate credit to the original author(s) and the source, provide a link to the Creative Commons license, and indicate if changes were made. The Creative Commons Public Domain Dedication waiver (http://creativecommons.org/ publicdomain/zero/1.0/) applies to the data made available in this article, unless otherwise stated. to maximize advantage from feeds in animal system. In this direction, many technologies have been developed so far, but for several reasons, they have not been adopted by the end-users, especially those having limited finance and poorly skilled [1]. The complete feed system is one of the latest developments in this context to exploit the potential of locally available animal feed resources in the best possible way.

Balanced and economical feeding of livestock is extremely important for optimum productivity. Lower livestock production is mainly due to the scarcity of feeds and unbalanced feeding practices. To minimize feed costs and labor, and to maximize production is the need of the time and can be achieved by blending concentrate, mainly comprised locally available by-products and roughage portions of the ration to form complete feed/diet, synonymously termed as total mixed ration (TMR). Complete feed with the use of fibrous crop residue is a noble way to increase the intake and to improve feed utilization and animal production performance. The complete feed system is being increasingly appreciated as it allows expanded the use of agro-industrial byproducts, crop residues and non-conventional feeds in livestock ration for maximizing production and minimizing feeding cost.

\section{Benefits of Complete Feed System}

The merits of complete feed are related to stable rumen environment for optimum fermentation with minimal fermentation losses and fluctuation in the release of ammonia, better utilization of rumen non-protein nitrogen, and stabilization of the acetate 
to propionate ratio which favors normal fat synthesis and enhancement of utilization of low-grade roughages $[2,3]$. Feeding complete feed ensures better consumption, thereby reduces wastage. In this system, the high yielders are allowed to realize their potential enabling them to eat according to their yield while avoiding wastage by low yielder [4].

Complete feed avoids selective refusal of unpalatable dietary portions, thus has provision for incorporation of nonconventional feed resources to economize animal feeding. Waste materials - such as waste paper [5], cotton-seed hulls [6], cotton straw [7,8], lentil straw $[9,10]$, sewen grass, mesquite pods, groundnut straw, tumba oilcake, taramira oil cake and groundnut hulls [11], forest grasses [12], sweet sorghum bagasse (SSB) [13-18], tree foliage [19-22], spent maize cobs [23], sugarcane bagasse pith [24], crop residues [25-27], poultry dropping [28], babul pods [29-31], olive cake [32], neem seed cake [33,34], karanja seed cake [34], and guar meal [35,36] - have been successfully incorporated in complete diets for livestock, thus lower feeding costs.

The complete feed has a balanced ratio of concentrate to roughage portions, reduces eating and rumination time, and thus increases resting time. The stall feeding system of livestock with complete feeds during climatic vagaries (drought, famine, and snow storms) has been advocated [1,37]. Sharma et al. [11] suggested that highly fibrous unconventional feedstuffs could be incorporated to form complete economic rations for sustaining sheep farming during feed scarcity in arid region. Singh et al. [27] indicated that goats could be maintained under stall feeding with complete diets containing high proportion of crop residues (gram or arhar straw). Furthermore, it has been reported that supplementation of the complete feed in block form during feed scarcity in semiarid region helped grazing ewes to maintain their body weight (BW) compared to unsupplemented ewes [38]. Feeding complete feeds appear superior to grazing plus supplementation in terms of dry matter (DM)/ nutrient intakes and animal performance, thus can be recommended as an alternative to such feeding strategy for sheep production, especially where the pastures are highly eroded and need resting for regeneration or curing [37,39].

\section{Feeding Complete Feed}

Several studies have been carried out for assessing the effects of feeding complete feeds in different ruminant livestock species on various aspects as under:

\section{Effect of complete feed on in vitro fermentation characteristics}

The chemical analysis of feedstuffs provides idea only about nutritive composition but does not give information about their fermentation values [40], which is important for ruminant digestion. In vitro rumen fermentation technique, a rapid method of analysis has widely been used to study feed degradation, detect small differences in fermentation characteristics between feedstuffs and allow more frequent sampling. This technique enables selection of feed or feed constituents for high efficiency of microbial protein synthesis in rumen along with high DM digestibility and provides a basis for the development of ruminant feeding strategies to maximize substrate fixation into microbial cells [41].

In in vitro studies, supplementation of complete feeds with different feed additives has been reported to improve the nutrient degradability by several workers. Mir et al. [42] observed increase in in vitro DM degradability (IVDMD) and in vitro organic matter degradability (IVOMD) on supplementation of different herbs at $2 \%$ and $3 \%$ level in complete feeds for goats. Ganai et al. [43] also reported that degradability of nutrients (DM, OM and neutral detergent fiber $[\mathrm{NDF}]$ ), total gas production (TGP), total rumen nitrogen, and total volatile fatty acid (TVFA) concentration in in-vitro system was significantly improved when bajra straw-based complete feed was supplemented with Bhringraj herb at 3\% DM in comparison to un-supplemented complete feed at $48 \mathrm{~h}$ incubation. In another experiment, Ganai et al. [44] again reported improvement $(p<0.01)$ in IVDMD, IVOMD and IVNDFD as well as TGP on supplementation of yeast to bajra straw and bajra straw-based complete feed. Likewise, Nehra et al. [45] concluded that live yeast culture supplementation improved $(p<0.01)$ IVDMD and IVOMD of dew bean straw-based complete feeds; besides, the straw could be optimally incorporated in the complete feed up to $60 \%$ level without any adverse effect. While determining the best possible level of thermotolerant yeast for sheep diet by in vitro fermentation experimentation, Harikrishna et al. [46] reported that level up to $3 \mathrm{~g} / \mathrm{kg}$ could be incorporated in adult sheep rations economically. Similarly, incorporation of enzymatic extract of Cellulomonas flavigena in TMR increased in vitro degradation of cellulose from forages that are fed to ruminants [47]. Thakur and Shelke [48] assessed the effect of different periods of storage and temperatures of TMR containing exogenous fibrolytic enzymes (EFEs) on enzyme activity and in vitro digestibility and concluded that there was no adverse effect of storage (up to 60 days) and heating (up to $80^{\circ} \mathrm{C}$ ) of TMRs on cellulose and xylanase activities and in vitro fiber digestibility. Grewal et al. [49] assessed the effect of different metabolizable energy (ME) $(100 \%, 110 \%$ and $120 \%$ National Research Council) and undegradable protein (UDP) $(24 \%, 32 \%$ and $40 \%$ of crude protein [CP] [16.8\%]) levels on the in vitro fermentation of complete feeds and showed that the diet containing ME at 110 or $120 \%$ of NRC (2001) with low UDP ( $24 \%$ of dietary $\mathrm{CP}$ ) supplemented with niacin gave the best response for nutrient digestibility and ME availability. Singh and Srinivas [50] assessed associative effect of cereals and oil cakes in concentrate supplements 
and complete diet for ruminants on in vitro fermentation kinetics and reported that in vitro gas production (IVGP) pattern of maize and oat-based concentrate supplement in complete ration mixture were comparable; however, the extent of IVGP on maize-based ration was better than sorghum-based ration and urea-mineral salt fortification yielded better improvement in fermentation pattern on maize-based ration than either sorghum or oat-based rations. Singh [51] showed that incorporation of slow release urea up to $30 \%$ of $\mathrm{CP}$ in TMR with niacin at $600 \mathrm{ppm}$ level resulted in highest efficiency and maximum microbial mass production as compared to other replacement levels of CP $(10 \%$ and $20 \%$ ) and niacin in in vitro fermentation studies. Likewise, Grewal et al. [52] reported that combination of niacin and vitamin E supplementation improved the in vitro utilization of complete feed.

Beneficial effects of incorporating nonconventional feedstuffs in complete feeds on in vitro rumen fermentation pattern have been observed. Jakhmola et al. [20] reported that inclusion of Calligonum polygonides leaves in sewan (Lasiurus sindicus) grassbased complete diets for ruminants had a potential to positively affect rumen metabolism in vitro. Goswami et al. [35] reported that IVDMD and IVOMD decreased by replacing groundnut cake (GNC) with guar (Cyamopsis tetragonoloba) meal in concentrate portion of TMRs at all $(25 \%, 50 \%, 75 \%$ and $100 \%)$ levels, but depression $(\mathrm{p}<0.05)$ was observed in TMR's containing $50 \%$ or more replacement levels. Likewise, Ramachandra et al. [53] concluded that the pulse by-products (straw and chunnies) based complete diets with the different levels of rate of gas production $(\mathrm{k})$ and partitioning factor could increase $(\mathrm{p}<0.01)$ the microbial biomass synthesis under in vitro fermentation.

\section{Effect of feeding complete feed on DM and nutrient intake}

Increased intake of DM and nutrients in different ruminant species on complete feed system compared to conventional feeding system has been reported by several workers $[7,8,10,12,25,54-59]$. Complete feeding system is considered better over separate feeding system [60]. Complete ration has beneficial effects in terms of utilization of low-grade roughages; besides, its densification into feed blocks $[19,26,61]$ or extrusion of the complete mash feed into pellets $[7,8,12,14,17,27,62]$ distinctly improves the $\mathrm{DM} /$ nutrient intake and nutritive value of mash diet, thereby ensures efficient utilization of the feed [63]. A higher intake, therefore, gives scope for using cheap ingredient and various bulky by-products that are available locally to economize livestock feeding.

\section{Effect of feeding complete feed on nutrient utilization}

Feeding complete diet stabilizes ruminal fermentation that improves efficiency of nutrient utilization in ruminants [3]. Feeding of ammoniated lentil (Lens culinaris) straw-based TMR to growing Barbari kids improved digestibility of various nutrients as well as DCP content $(p<0.01)$ of the diet [9]. In another experiment, Mudgal et al. [10] reported improvement in digestibility of various nutrients as well as TDN content $(\mathrm{p}<0.01)$ of the diet for kids compared to those fed the straw ad libitum. Likewise, Kishore et al. [57] reported that crop residues (maize stover $[\mathrm{MS}]$, red gram straw and black gram straw) based complete rations provided better nutrient supply in terms of higher DCP and TDN values and intakes of $\mathrm{DM} /$ digestible nutrients/DE and ME to Nellore rams compared to conventional ration. Similar results have been reported by Sharma et al. [58] in calves fed complete feed in mash form compared to those fed the diet in conventional form.

Utilization of poor quality feedstuffs can be improved by their incorporation in complete diet rather than feeding separately along with concentrate mixture. However, adequate DCP content in crop residue-based complete feeds is necessary to meet the maintenance and growth requirements of the animals. Senani et al. [23] reported that ground maize cobs could replace ragi straw completely in the TMR for lambs without any significant effect on DM intake and nutrient digestibility. Kumar et al. [64] concluded that a dietary CP level of $13.5 \%$ in complete feed was sufficient for successfully and economically raising of calves with no significant differences for feed intake and utilization compared to other higher $(15 \%$ and $16.5 \%)$ levels. The use of urea and molasses in paddy straw-based complete diets made from locally available ingredients might maximize and economize the production of livestock through improved degradability and utilization of nutrients and might be accessed through feeding trials in animals [65]. Likewise, Pandya et al. [66] reported similar intake of DM, CP, DCP and TDN as well as average daily gain (ADG) in crossbred calves fed complete feed based on wheat straw $(30 \%)$ and conventional ingredients, complete feed based on sugarcane bagasse (30\%) and nonconventional ingredients or conventional feed with higher protein utilization efficiency in both the complete diets fed groups. While evaluating three monsoon herbages processed into complete pellet feed for feeding to Barbari male kids during fodder scarcity periods, Tripathi et al. [67] reported that digestibility of DM, $\mathrm{OM}$ and $\mathrm{CP}$ was higher $(\mathrm{p}<0.05)$ in kids fed Tephrosia purpurea based diet possibly due to higher $\mathrm{CP}$ content and therefore intake, while cellulose digestibility was higher $(\mathrm{p}<0.05)$ in those fed Dactylotennium aegypticum based diet.

Processing of the complete feeds has been reported to improve the nutrient utilization in ruminant animals. Incorporation of crop residues as a roughage source in TMR for ruminants and their further processing (densification/pelleting) is one of the practical ways of improving their utilization. The physical form of the diet can affect potential rate of consumption with densified/pelletized diets ingested 
more rapidly than those in mash form. In an experiment carried out by Afzal et al. [19] on Corriedale lambs, significant $(\mathrm{p}<0.05)$ improvement in feed conversion efficiency with marked reduction in cost of production by feeding complete feed block has been reported, while $\mathrm{DM} /$ nutrient intake and digestibility of $\mathrm{DM} /$ gross nutrients, nutritive value and retention of major minerals did not change between the groups. However, Singh et al. [61] reported higher $(\mathrm{p}<0.05)$ feed intake in calves fed wheat and rice straw-based complete feed in block forms as compared to those fed mash forms of complete feeds, while the digestibility of DM and gross nutrients along with different nutrient intakes did not differ among the calves of dietary treatment groups. Furthermore, Ghosh and Chatterjee [68] reported that MS-based complete feed block could successfully replace the straw and tree leaves based diet supplemented with concentrate mixture in conventional form for yaks without any adverse effect on voluntary feed intake and nutrient digestibility during winter feeding. In contrast, Khan et al. [69] reported that physical form (mash vs. block) of the diet had no significant effect on nutrient digestibility in lambs except CP. Likewise, pelleting of complete diets has been reported to improve the voluntary feed intake and nutrient utilization to enhance animal performance. Waje et al. [12] reported higher intake and digestibility of nutrients in growing crossbred calves fed mixed forest grasses-based complete pellet feed as compared to calves fed either conventional or TMR diets. Another processing method for feeding complete diets is expansion-extrusion which also has proved to be better than feeding complete diet in mash or conventional forms. To identify the appropriate processing method for efficient utilization of SSB after blending with concentrate in complete diets for buffalo calves $[14,17]$ and growing lambs [18], expander-extruded pellet complete diets were observed to be better in terms of nutrient utilization efficiency and microbial $\mathrm{N}$ supply than chopped or mash forms of the complete diets. The complete diet based on paddy straw incorporated at 50\% level was more palatable to sheep when it was expander-extruder pelleted and such processing improved the nutritive value of the diet [70]. In contrast, Reddy et al. [62] reported that expansion-extrusion pelleting of complete diets significantly $(p<0.001)$ increased the voluntary feed intake compared to the similar mash diets with no effect on digestibility of nutrients. Likewise, Datt et al. [59] reported that blending of paddy straw into complete diets significantly increased digestibility of protein, nitrogen balance and DCP and TDN intakes compared to conventional diet; however, expansion-extrusion processing of mash diet did not have additional advantage over mash diet.

Supplementation of feed additives in complete diets improves their nutritive value and nutrient digestibility in ruminant livestock besides have health promoting and feed economizing effects. Harikrishna et al. [46], while determining the optimum level of thermotolerant probiotic yeast in straw-based complete diet for lambs, reported that yeast had potential at $1-3 \mathrm{~g} / \mathrm{kg}$ level in improving digestibility of nutrients, intake of DCP and $\mathrm{ME}$, and $\mathrm{N}$ retention; however, incorporation of $1 \mathrm{~g} / \mathrm{kg}$ level appears to be economical with fattening diets that may be beneficial for livestock producers. Futhermore, Bhima et al. [71] reported that supplementation of yeast at $0.1 \%$ level in straw-based complete diet improved the digestibility of DM, CF, Neutral Detergent Fiber NDF, acid detergent fiber, cellulose, hemicellulose as well as TDN and ME value of the diet without affecting DM/nutrient intakes and $\mathrm{N}$ balance in Murrah buffalo steers; however, beyond $0.1 \%$ of supplementation no significant effect on nutrient digestibility and intake were observed. Likewise, live yeast culture supplementation to green gram straw-based complete feed in block form improved nutrient utilization through increased ruminal bacterial count leading to increased rate of fiber digestion in the rumen as well as increased flow of microbial protein from the rumen [72]. In an experiment carried out by Sehgal et al. [73] to assess the effect of incorporation of fungal zoospores of Orpinomyces joyonii in paddy and wheat straw-based TMRs for lactating buffaloes, improvement $(\mathrm{p}<0.05)$ in digestibility of all the nutrients as well as the \%TDN content of the diet has been reported.

The roughage:concentrate $(\mathrm{R}: \mathrm{C})$ ratio in complete feed may vary in accordance to the production performance of animals. Reddy et al. [62] reported that red gram straw could efficiently be utilized up to $50 \%$ level in expander-extruder pellet complete diets for growing goat kids. Ammoniated wheat straw to the extent of $70 \%$ in complete feed for buffalo heifers has been found to be more economical [74]. For growing lambs, the optimum level for incorporation of groundnut haulms/straw in complete feed was suggested to be $60 \%$ [75,76]. Likewise, Dhuria et al. [77] reported that mustard straw could be incorporated in complete feed for sheep up to $60 \%$ level without much adverse effect on voluntary feed intake and nutrient utilization. Moreover, it has been reported that SSB could be incorporated at 50\% [15] while as sweet sorghum stover could be incorporated at 60\% [78] level replacing conventional roughages such as sorghum stover and MS in complete diets for sheep. Similarly, Nagalakshmi et al. [79] reported that red gram stalks could be incorporated up to $40 \%$ level in complete diets for buffalo bulls, while incorporation of the same at 50\% level depressed nutrient digestibility and lowered nutritive value of the diet. In an experiment carried out by Rajamma et al. [80] to study the effect of supplementation of EFEs in TMR for adult buffalo bulls on nutrient utilization, it has been reported that nutrient digestibility improved irrespective of the R:C ratio in the diet. Veerannapet et al. [81] reported that MS could be included at 50-60\% level in mash complete ration for optimum nutrient utilization in male 
lambs. Sinha et al. [82] reported similar DM and OM intakes in buffaloes and cattle fed TMRs with different ratios $(60: 20: 20,40: 30: 30$, and 20:40:40) of concentrate, wheat straw and green fodder; however, heat production and oxygen consumption were lower while urinary $\mathrm{N}$ excretion, respiratory quotient and methane emissions at similar level of DM intake were higher in buffaloes than that in cattle, with higher proportion of concentrates in the diet decreased methane emissions linearly in both the species.

Feeding complete diet provides scope for incorporation of nutritious non-conventional feeds resources in concentrate or roughage component by avoiding selective eating of palatable components by animals. Mishra et al. [21] reported that fallen tree leaves (FTL) as replacement to pearl millet stover could safely be used up to $20 \%$ level as a roughage component of complete feed in block form without any adverse affect on nutrient utilization efficiency and microbial $\mathrm{N}$ supply; however, increasing the level of FTL to $30 \%$ in the diet showed declining trend on nutritional performance parameters. In an attempt to replace concentrate mixture by leaf meal in complete feed for sheep, Ganai and Beigh [22] reported that concentrate mixture could be efficiently replaced by leaf meal up to $30 \%$ level with no adverse effect on nutrient utilization. Babul pods could be incorporated safely in TMRs of lactating [29] and pregnant [31] goats to the extent of $16.5 \%$ without affecting the nutrient utilization, $\mathrm{N}$ and macro mineral balances; however, could be utilized up to $25 \%$ in the diet after $\mathrm{Ca}(\mathrm{OH})_{2}$ treatment. Similarly, Samanta et al. [83] reported that Leucaena leaf meal could replace mustard cake in concentrate portion of complete diets up to $30 \%$ safely and inexpensively without affecting nutrient utilization in Barbari goats. In a study carried out by Bhatta et al. [84], while assessing the effect of feeding high tannin containing Prosopis cineraria leaves in complete feed mixture on the performance of lambs and kids, reported that feed efficiency ratio was the best in animals fed on complete feed containing 50\% leaves. Tiwari et al. [24] reported that wheat straw could be completely replaced by urea ammoniated sugarcane bagasse pith in complete diet for crossbred bulls as source of dry roughage without any adverse effect on DM/nutrient intakes, digestibility of nutrients $(\mathrm{CP}$ and $\mathrm{EE}$ ), and balances of $\mathrm{N}$ and major macrominerals ( $\mathrm{Ca}$ and $\mathrm{P})$. Olive cake, a highly fibrous feed is a better substitute to wheat straw. Ensiling process is a feasible means of converting and utilizing olive cake into reasonably nutritious feed when treated with urea. Such a product as part of complete ration could make a significant contribution to sheep production under intensive farming [36]. Likewise, Goswami et al. [35] reported no difference with respect to $\mathrm{DM} /$ nutrient intakes and digestibility of nutrients among crossbred calves fed TMRs prepared by replacing $(50 \%$ and $75 \%$ ) GNC with guar meal.

\section{Effect of feeding complete feed on growth}

Feeding of small ruminants with crop residues-based complete rations appears to be the promising feeding system for improving their productivity in agricultural countries like India. Complete feed system improves nutrient utilization that supports higher growth performance and reduces the cost/ $\mathrm{kg}$ live weight gain, thus is economical in comparison to conventional feeding system. Several studies have observed the beneficial effect of feeding complete ration on the growth performance of animals. Malisetty et al. [16] reported that Nellore lambs fed SSB-based complete diet had the ADG almost similar to those animals fed lucerne hay plus maize silage ad libitum. Nagi et al. [25] reported higher $(\mathrm{p}<0.01)$ ADG and nutrient utilization efficiency in Deccani lambs fed ground paddy straw-based complete diets compared to those fed conventional diet. Similarly, Chaturvedi et al. [37] reported that complete feed offered to Avikalin lambs under stall feeding system appeared superior to grazing plus supplementation system in terms of intake and animal performance. In another experiment, Chaturvedi et al. [38] observed that supplementation of complete feed in block form to grazing ewes during feed scarcity in semi-arid region helped in sustaining their BWs due to better nutrient availability compared to unsupplemented ewes maintained on sole grazing that lost $1.52 \mathrm{~kg} \mathrm{BW}$. Bartley [85] observed that feeding complete ration in pelleted form containing $25 \%$ sun-cured alfalfa hay to the calves significantly increased feed consumption and weight gain compared to calves fed milk starter and hay separately in conventional pattern. Florek and Lewicki [86] reported higher ADG and DCP intake in fattening bulls fed complete feed. Enhanced $\mathrm{N}$ balance and growth response in sheep fed complete rations containing legume straw has also been reported by Bonsi et al. [87]. Sorghum straw, soybean straw, and corn cobs-based complete rations could maintain adult Osmanabadi goats satisfactorily with DCP and TDN intakes higher than ICAR [88] recommendations with no loss in BW [89]. Similarly, Venkateswarlu et al. [90] reported the significant effect on growth rate (93.5$103.3 \mathrm{~g} /$ day) and feed conversion efficiency in lambs fed crop residue-based complete ration in comparison to traditional grazed animals ( $48.5 \mathrm{~g} /$ day) with no concentrate supplementation. Poor quality crop residues like groundnut haulms and red gram bhusa inclusion into complete feeds have also been reported to enhance intake without affecting digestibility, which resulted in improved growth performance and feed conversion efficiency in bucks [91]. However, Sharma et al. [58] reported no significant difference in $\mathrm{ADG}(509,556$ and $496 \mathrm{~g} /$ day) of crossbred calves fed either wheat straw ad libitum and concentrate mixture separately in conventional form or the wheat straw-based complete feed in mash and block form, although the calves fed complete mash feed gained higher BW than calves in other dietary treatment groups. The CP level of $15.4 \%$ 
in complete pellet feed has been reported beneficial for commercial goat farming under stall feeding system [92]. Likewise, Nagpal and Singh [93] observed comparable growth performance and feed utilization efficiency in 3.5-year-old camel calves on complete pellet diets containing either $8.34 \%$ or $10.40 \% \mathrm{CP}$ and concluded that they could be successfully and economically raised on dietary protein level of $8.34 \% \mathrm{CP}$ and $65 \%$ TDN.

The level of roughage source in complete feed can be variable depending on production performance of animals; besides, the animal response varies with $\mathrm{R}: \mathrm{C}$ ratio. Ganai and Beigh [22] reported that replacing concentrate mixture by leaf meal in complete rations for sheep at $30 \%$ level resulted in best growth performance in terms of total gain and ADG of lambs. Prasad et al. [75] reported that the optimum level of groundnut haulms as sole roughage source in complete ration could be $60 \%$ without affecting the growth performances, feed efficiency and nutrient digestibility in growing lambs. Likewise, higher $(p<0.05)$ nitrogen balances were observed in Nellore $\times$ Deccani lambs fed complete mash ration based on MS incorporated at $50 \%$ level compared to those fed MS-based rations included at $60 \%$ and $70 \%$ levels [81]. Mattoo and Ganai [94] reported highest weight gain in Corriedale sheep fed 40\% roughage-based complete diet among the groups fed three iso-nitrogenous complete rations containing $40 \%, 50 \%$ and $60 \%$ roughage (rice straw and mixed tree leaves). Venkateswarlu et al. [95] concluded that inclusion of sorghum straw at $50-60 \%$ level in the complete ration could be practiced for feeding of growing lambs without affecting the growth rate. Furthermore, Dhore et al. [96] were of the same opinion that sorghum straw could be used as a sole roughage source at $60 \%$ level in complete pellet feed for intensive goat production. MS, a potential cereal crop residue hitherto unused could be incorporated as roughage component in complete rations at $50-60 \%$ level for obtaining optimum growth with better feed efficiency in growing lambs [97].

Inclusion of nutritious non-conventional but safe feed resources in concentrate or roughage component of the complete feed has proved to be beneficial for promoting the growth performance of ruminants. Ammoniation of lentil straw for use in TMR might be an effective way for improving nutrient utilization to get better growth response along with reduction in cost of feeding small ruminants $[9,10]$. SSB and leaf residues remaining after juice extraction could be used as a major component of complete feeds in diverse physical forms mitigating the threat of feed shortage [13]. Senani et al. [23] reported that ground spent maize cobs could replace ragi straw completely in the TMR of lambs without affecting the weight gain. Tiwari et al. [24] reported that ammoniated sugarcane bagasse pith could be used up to $50 \%$ in the complete diet of growing cattle bulls without any adverse on their growth performance; however, inclusion of the same at higher levels resulted in significant $(\mathrm{p}<0.05)$ reduction in growth rate. Kushwaha et al. [30,31] reported that babul (Acacia nilotica) pods might be incorporated up to $33 \%$ in concentrate mixture of TMR for pregnant and lactating goats without affecting growth rate and it might be increased up to $50 \%$ by treating with $\mathrm{Ca}(\mathrm{OH})_{2}$ before use. Neem (Azadirachta indica) seed cake could be incorporated into complete diet for lambs after detoxification without any deleterious effect on growth and meat quality [33]. Goswami et al. [35] reported improved live weight gain and feed conversion efficiency in crossbred calves fed TMR in which $50 \%$ GNC in concentrate portion was replaced with guar meal; while at $75 \%$ replacement, there was decrease in live weight gain, ADG and feed conversion efficiency; however, these negative effects were overcome by added sweetener in the ration. In another similar experiment, Sharma et al. [36] reported no adverse effect on nutrient utilization efficiency and thereby growth rate by feeding 5\% guar meal as protein supplement in compressed complete diets to growing calves. Monsoon herbages (D. aegypticum, Cenchrus ciliaris, and T. purpurea) have potential for feeding to kids in the form of complete pellet feed during feed scarcity periods for supporting their optimum growth [67]. Conventional protein supplement alone or in combination with energy source with nutritionally improved poor quality crop residues like fermented wheat straw could be used as complete feed for growing animals in comparison to conventional feeding system, where roughage is supplemented with concentrate mixture [98]. Rekhate et al. [99] reported that arhar straw-based complete pellet ration could be fed to goats for optimum weight gain under intensive system of management. Similarly, tapioca leaves and tea waste $(45: 15)$ could be incorporated in complete pellet ration for growing kids with no significant effect on average weight gain and feed and protein conversion efficiencies compared to those fed guinea grassbased pellet ration as control [100]. Radhakrishnan and Balakrishnan [101] reported that neem (A. indica) leaves could be incorporated up to $40 \%$ level replacing groundnut haulms in complete rations without affecting the growth rate in kids.

Various studies have shown enhancement in growth performance of animals fed processed complete feeds. Feeding complete feed in block form to lambs resulted in higher ADG and $\mathrm{N}$ retention in comparison to those fed complete mash feed [8]. Furthermore, Singh et al. [61] reported higher $(\mathrm{p}<0.05) \mathrm{BW}$ gain in calves fed rice strawbased complete feed blocks as compared to those fed mash form of the same complete feed. However, Ghosh and Chatterjee [67] reported no adverse effect on BW change in yaks during winter fed MS-based complete feed in block form compared to those fed straw and tree leaves based diet supplemented with concentrate mixture in conventional form. In a similar experiment, Medhi et al. [102] reported that feeding of 
complete feed in block form to lactating yaks during winter were comparable to silages with or without supplementation and had beneficial effects in terms of retention of loss in BWs compared to those on free grazing. The complete pellet feed is a technology to ensure proper nutrient supply and optimum production from the domestic animals. Waje et al. [12] reported that pelleting of complete ration improved $(p<0.05)$ the growth rate of crossbred calves as compared to those fed either conventional or TMR diets; however, the cost of feeding $/ \mathrm{kg} \mathrm{BW}$ gain remained comparable. Likewise, Singh et al. [27] reported that feeding crop residues-based complete pellet diet improved feed conversion efficiency and reduced cost of feeding over complete mash diet in goat kids. Madhavi et al. [33] reported higher $(\mathrm{p}<0.05)$ ADG and lower cost per kg gain in Nellore lambs fed complete pellet diets in comparison to those on mash diet with no significant differences for carcass characteristics. Nagpal [103] reported that camel calves could be fed on complete pellet diet with $9.94 \% \mathrm{CP}$ and $63.35 \%$ TDN for better growth rate and feed conversion efficiency. In addition, it has been reported that incorporation of urea at $1 \%$ in roughage-based complete pellet diets for growing camels could positively improve nutrients intake, digestibility, growth performance, and feed conversion efficiency [104]. Expanderextruder processing of roughage-based complete diets improves nutrient utilization efficiency, results in better growth performance and may form an economic ration for growing ruminants. Nagalakshmi and Reddy [8] assessed on farm performance of lambs and reported higher $(\mathrm{p}<0.01)$ ADG and feed utilization efficiency, and lower $(p<0.01)$ cost of feed per $\mathrm{kg}$ gain in animals fed cotton stalks based expander-extruder processed complete diet in comparison to those fed conventional ration. SSB [14] or sweet sorghum crushed residue [17] might be economically used as an alternative roughage source to sorghum straw and feeding of complete rations in the form of expander-extruder pellets proved superior over chopped and mash forms of the same ration in terms of higher $(p<0.01)$ ADG, lower $(p<0.01)$ FCR and cost per kg gain. Furthermore, Reddy et al. [62] reported that expander-extruder pelleting of complete diets significantly increased the weight gain in goats.

Feed additives supplementation in complete diets improves nutrient utilization promotes higher growth rate in animals. The addition of an enzymatic extract of $C$. flavigena to forage in TMR did not improve digestion, and thus productive performance in lambs at the doses $(0,5.0$ and $7.5 \mathrm{~mL}$ of extract per kg DM of TMR) evaluated [47]. However, incorporation of superior anaerobic fungal (Neocallimastix sp. GR-1) zoospores in wheat straw-based complete feed for Murrah male buffalo calves significantly increased nutrient digestibility and DE value that enhances feed efficiency (by 28.7\%) and BW gains (by 16\%) [105].
Effect of feeding complete feed on quantity and quality of milk

Blending of roughage and concentrate portions into complete diet increases its energy density [3] and provide all the nutrients in required proportions, thus improve performance of dairy animals [106-109]. Besides, the physiological and economic problems encountered with ad libitum feeding of both the roughage and concentrate portions of the ration separately get reduced. Maximum benefits can be realized by incorporating such feeds as ingredients that are most economically purchased, transported and stored. Nagalakshmi and Reddy [8] in one on-farm trial reported higher $(\mathrm{p}<0.01)$ milk yield and feed cost per kg fat corrected milk (FCM) in buffaloes fed cotton stalks based expander-extruder processed complete diet compared to those fed conventional diet. In addition, Medhi et al. [102] reported that during winter, lactational performance of yaks fed complete feed in block form was higher $(\mathrm{p}<0.05)$ compared to those on free grazing. Feeding complete feeds significantly increased $(\mathrm{p}<0.05)$ milk production in buffaloes [107] and crossbred cows [109] as compared to conventional rations. Holter et al. [110] reported that feeding with the blended diet resulted in more milk with higher efficiency of ME utilization for milk production. Das et al. [111] reported higher average milk yield in complete feed block fed than in mash fed lactating buffaloes during an on-farm trial and farmers were of opinion that complete feed blocks not only enhanced milk yield but were also easy at feeding and storage. However, Rakes [112] concluded that complete rations containing $13-14 \% \mathrm{CP}$ supported milk production at par with that obtained with conventional ration in dairy animals. Furthermore, Kumar et al. [113] reported that feeding of TMR to lactating buffaloes had no significant effect on milk yield compared to those fed the diet in conventional form.

Feeding of complete diets to dairy animals has variable results on milk composition. Nagalakshmi and Reddy [8] reported higher $(\mathrm{p}<0.01)$ milk fat and $6 \%$ FCM yield in buffaloes fed expander-extruder processed complete diet compared to those fed conventional diet in one on-farm trial, with no effect on milk solid-not-fat (SNF) content. In attempts to include non-conventional feed resources in the ration of dairy animals, it has been reported that babul pods could be included in the TMR of lactating goats safely up to $16.5 \%$ and even at higher levels up to $25 \%$ in diet after $\mathrm{Ca}(\mathrm{OH})_{2}$ treatment without affecting milk production and its composition [30]. Similarly, Raj et al. [34] concluded that detoxified neem and karanja cake could be incorporated in TMRs of medium producing dairy cattle (5-8 L milk/day) replacing standard soybean meal without adversely affecting milk composition and milk production efficiency in crossbred dairy cows. Kumar et al. [113] reported higher SNF, protein, total solids and polyunsaturated fatty acid content in milk of buffaloes fed TMRs compared 
to those fed the diet in conventional form. Likewise, Villavicencio et al. [114] found no significant difference in milk production or milk composition (except SNF) of high-producing cows fed complete feeds during long-term studies. O'Neil et al. [115] reported increased level of protein content in milk on TMR feeding as compared to separate feeding of roughages and concentrate.

$\mathrm{R}$ : $\mathrm{C}$ ratio in the complete diet for dairy animals is an important factor regulating the quality of milk. The most common dietary cause of low fat in milk is the diet containing a low level of forage and/or a high level of concentrate. The low milk fat is often confounded by the fact that low forage diets are often associated with high milk production which itself tends to lower fat $\%$. Only $20 \%$ roughage in a complete diet could cause a cow to secrete milk with lowfat content, while $40 \%$ roughage level in complete ration produced significantly more FCM and milk fat than that of a $30 \%$ roughage ration with no significant differences in SNF [116,117]. Improvement in the total and FCM yield was noticed in buffaloes given a complete pellet diet containing 30\% roughage [118]. Nelson et al. [119] reported that FCM production and $\%$ SNF significantly decreased among animals consuming the all forage ration compared to other rations, and $\%$ milk fat also showed highly significant linear decrease with increase in concentrate portion in complete ration. Owen et al. [120] fed dairy cows on complete diets containing various levels of milled straw and concluded that complete diets should contain a minimum of $24 \%$ milled straw. The optimum R:C ratio was not likely to exceed 60:40, with 50:50 ratio adequate for high yielding cows. With the increased level of straw from $20 \%$ to $50 \%$ in the complete diet for dairy cows, the fat percentage increased progressively while milk yield and SNF declined [121].

\section{Effect of feeding complete feed on rumen fermenta- tion and hemato-biochemistry}

Feeding complete feed to ruminants results in more uniform load on the rumen which is associated with less fluctuation in the release of ammonia so that rumen non-protein nitrogen is more efficiently utilized [3]. Complete rations comprising of locally available crop residues as roughage source on feeding provide conducive rumen environment for better nitrogen utilization and higher TVFA production than conventional ration [2]. Besides, the activities of different ruminal enzymes responsible for fiber degradation have been reported to be higher in animals fed complete ration as compared to animals fed conventional ration [122].

Several workers have observed no adverse effects of feeding different unconventional feedstuffs based complete rations on rumen fermentation. Feeding ammoniated lentil (L. culinaris) straw-based TMR to growing Barbari kids resulted in higher $(\mathrm{p}<0.05)$ total and ammonia-N with comparable $\mathrm{pH}$ and TVFA contents in rumen fluid compared to those fed untreated straw-based TMR [9]. However, Mudgal et al. [10] reported reduction $(\mathrm{p}<0.05)$ in $\mathrm{pH}$ and improvement $(p<0.05)$ in TVFA production with comparable total and ammonia-N in kids fed ammoniated lentil strawbased TMR compared to those fed the straw ad libitum. Sharma et al. [11] reported no significant effect among the feed sources on rumen fermentation pattern in sheep fed various complete rations based on unconventional feed resources of arid zone of India. Mishra et al. [21] reported that inclusion of FTL to replace pearl millet stover in complete feed block diets for sheep increased ammonia-N, total-N and ciliate protozoa population with no effect on VFA concentrations. Likewise, replacing ragi straw with ground spent maize cobs at $50 \%$ and $100 \%$ level in the complete diets for lambs resulted in non-significant effect on various rumen fermentation metabolites; however, led to more favorable values for rumen metabolites along with increase in bacterial and fungal counts in the rumen [23]. Narasimha et al. [28] reported that the $\mathrm{H}^{+}$ion and TVFA concentrations were significantly $(p>0.01)$ higher in sheep than in goats while the concentration of total N, trichloracetic acid (TCA) insoluble N, food and protozoal N in SRL was significantly higher in goats than in sheep; however, ammonia and residual $\mathrm{N}$ concentrations did not differ significantly between sheep and goats by feeding complete mash diet containing poultry litter (35\%). Herbages (C. ciliaris, T. purpurea, D. aegypticum) could be conserved during monsoon season for feeding to the growing kids as complete pellets diets during fodder scarcity periods without any adverse effect on rumen fermentation characteristics [67]. Likewise, Ramachandra et al. [53] reported that pulse by-products based complete diets could significantly $(p<0.01)$ increase the rumen microbial biomass synthesis and suggested that the same could be tested for their microbial biomass efficiency in vivo.

Feeding complete feeds in different processed forms has been reported to be beneficial in animal system with respect to rumen fermentation by several workers. Complete pellet diet feeding causes changes in rumen fermentation pattern predominantly increases propionate production favoring glucose production for energy yield which is efficiently utilized for cellular growth and development, thereby reduces feeding/production cost of growing animals [123]. Significant $(p<0.01)$ variations among all the studied rumen metabolites were observed in goats fed arhar straw-based complete pellet ration in comparison to those offered sole arhar straw pellets with concentrate pellet supplementation [100]. Datt et al. [59] reported significantly $(\mathrm{p}<0.01)$ higher concentration of total $\mathrm{N}$, TCA precipitable-N, ammonia-N and TVFA in rumen liquor of sheep fed expander-extruder processed paddy straw-based complete diet than those fed the diet in conventional form. Likewise, Nagalakshmi and Reddy [70] reported lower ( $\mathrm{p}>0.05)$ ammonia-N and higher total- $\mathrm{N}$ in sheep fed processed paddy 
straw-based complete diets than those fed the diet in mash form, while, TVFA concentration was higher $(p<0.01)$ in SRL of lambs fed expander-extruder pellet diet. No adverse effects on rumen fermentation pattern and hemato-biochemical parameters were observed in sheep fed bajra straw [124], gram straw [125], and mustard straw [126] at 60\% level based complete feed in mash and block form.

Supplementation of feed additives in complete feeds promotes rumen fermentation in a favorable direction to enhance animal performance. Nehra et al. [72] concluded that live yeast (Saccharomyces cerevisiae) culture supplementation to green gram straw-based complete feed blocks promoted rumen fermentation which improved nutrient utilization resulted in stimulated growth of kids. Likewise, yeast supplementation to groundnut straw-based complete feed block could be beneficial to improve the performance of sheep due to a marked improvement in rumen fermentation pattern [127]. Sehgal et al. [73] reported improvement $(\mathrm{p}<0.05)$ in various rumen fermentation parameters (TVFA, total-N, ammonia-N, TCA perceptible-N and total no of zoospores/ $\mathrm{mL}$ SRL) in lactating Murrah buffaloes fed fungal (O. joyonii) zoospores incorporated paddy and wheat straw-based TMRs. Likewise, Kumar et al. [105] reported enhancement of nutritive value of wheat straw-based complete feed blocks with the incorporation of elite fungal zoospores through improvement in studied rumen metabolites (total-N, TCA-N, TVFAs, number of fungal zoospore and bacteria/mL SRL). Furthermore, Jha et al. [128] reported similar findings in buffalo calves fed wheat straw-based complete feed blocks incorporated with fungal (Neocallimastix spp.) zoospores and sulfur (1\% sodium sulfate). This technology developed to improve the nutritive value of wheat straw-based diets, can be used at the compound feed industry level for providing a well-balanced wheat straw-based complete feed rations to the animals at farmers door.

Complete ration is the best feeding model as it reduces problems of nutrient deficiencies in livestock fed on poor quality feed resources with no adverse effects on animal health by allowing a synchronous and fractionated supply of all essential nutrients for attaining maximum production potential. Sharma et al. [58] reported no significant difference in serum glucose, total protein, albumin and globulin concentrations among the crossbred calves fed the diet in conventional form or the complete feed in mash and block form, whereas serum total cholesterol and SGPT $(\mathrm{p}<0.05)$ and alkaline phosphatase $(\mathrm{p}<0.01)$ activities were significantly less and SGOT activities were considerably less in calves fed complete feeds in mash or block form compared to those fed the diet in conventional form. In addition, Singh et al. [61] reported comparable blood biochemical values in crossbred calves fed wheat and rice straw-based complete feed either in mash or block forms. Comparable hemato-biochemical parameters were recorded in growing Sahiwal calves fed on TMRs with three $(13.5 \%, 15 \%$ and $16.5 \%)$ levels of proteins and concluded that a dietary level of $13.5 \% \mathrm{CP}$ for calves is sufficient to maintain blood parameters within the normal range [64]. Tripathi et al. [67] concluded that monsoon herbages might serve as good roughage source for kid production if fortified appropriately with concentrate feeds to form complete pellet feed resulting no change in their hemogram. Blood biochemicals were within the normal physiological ranges in all the goats with no alterations in protein utilization and thus blood glucose, plasma urea-N and total serum proteins fed complete diets based on natural grass hay and concentrate mixture with replaced mustard cake by Leucenea leaf meal [83]. Nagpal and Singh [93] observed comparable levels for blood glucose, total protein, albumin, triglycerides, cholesterol and creatinine in camel calves fed complete pellet diets containing either 8.34 or $10.40 \% \mathrm{CP}$, while concentrations of serum urea, Ca and $\mathrm{P}$ were higher $(\mathrm{p}<0.05)$ in animals of group fed at $10.40 \%$ CP level. Similar results have been reported for male camel calves fed roughage-based complete pellet diets with different CP and TDN values [103]. Kumar et al. [113] also reported that the levels of blood glucose, blood urea nitrogen (BUN), $\beta$-hydroxybtyrate, non-esterified fatty acids and total immunoglobulin in lactating Murrah buffaloes were not influenced either by separate feeding of roughage and concentrate or TMR feeding. No difference has been reported in BUN level between the goats fed complete ration or concentrate and forage separately [129]. However, Gupta et al. [122] reported that feeding of complete ration to crossbred cattle in contrast to conventional feeding caused changes in blood biochemical parameters indicating improvement in nutrient utilization. Likewise, Delany et al. [130] reported higher blood glucose concentration in cows fed TMR as compared to those grazed in pasture and supplemented with concentrate. In addition, Nagpal et al. [131] observed improvement in serum bio-chemicals (blood glucose and serum proteins) by feeding complete ration to camel calves resulting in their better health status. Rekhate et al. [132] reported significant effect of feeding complete pellet diet on various blood biochemicals in goats, although all were in the normal ranges. Beigh and Ganai [133] concluded that leaf meal mixture could be used as alternative protein source to replace part (30\%) of conventional concentrate in TMR for raising lambs economically without any adverse effect on blood biochemicals and rumen metabolites. Ramulu et al. [134] concluded that dietary Zn supplementation of $140 \mathrm{ppm}$ to buffalo calves in sorghum stover based complete diets could be recommended for obtaining better immune response with no adverse effect on hematological constituents and other essential minerals availability. 
In spite of such great importance of complete feed system in ruminant feeding, the technology has remained confined to the organized farms only, as it is not economically feasible for small and marginal livestock farmers to purchase and operate the costly machinery required for blending the ingredients. As such, there is a dire need to extend the concept extensively to the field. In this direction, some limited efforts have been made by providing small-scale forage disintegrator and grinder cum mixer to the villages through local self-help groups on a community basis. Thus, to make this technology successful and viable for farmers, more efforts are needed.

\section{Conclusion}

Complete feed system for feeding ruminants is comparatively better option than conventional feeding of concentrates and roughages separately or grazing plus supplementation. This has advantages in provision of balanced diet to the ruminants and helping better utilization of the locally available feed resources, resulting in higher productivity along with reduction in feed cost and labor. Thus, the concept of complete feed system is becoming increasingly popular. However, lots of efforts are still needed to be taken for extending the concept extensively to the field.

\section{Authors' Contributions}

This review is a part of $\mathrm{PhD}$ thesis of the first author YAB, who carried out the research under the supervision of AMG. HAA helped in thorough revision of the manuscript. All authors have read and approved the final version of the manuscript.

\section{Acknowledgments}

The authors are grateful to the Directorate of Research, SKUAST-Kashmir for funding the work of the student under Rashtriya Krishi Vikas Yojana project entitled "Fortification of Poor Quality Straws for Quality Livestock Feeding" bearing no. SK-RKVY-AN-1.

\section{Competing Interests} interests.

The authors declare that they have no competing

\section{References}

1. Afzal, Y., Mattoo, F.A., Ganai, A.M. and Ahmad, H.A. (2009) Complete feed block technology - A boon to sheep farming. Livest. Int., 13(1): 4-7.

2. Konka, R.K., Kumar, D.S., Ramana, J.V., Ravi, A. and Rao, E.R. (2016) Fermentation pattern in Murrah buffalo bulls fed crop residue based complete rations vis-a-vis conventional feeding system. Anim. Nutr. Feed Technol., 16(1): 171-179.

3. Lailer, P.C., Dahiya, S.S. and Chauhan, T.R. (2005) Complete feed for livestock concept, present status and future trend: A review. Indian J. Anim. Sci., 75(1): 84-91.

4. Owen, J.B. (1979) Complete Diets for Cattle and Sheep. Farming Press Limited, Suffolk, England.

5. Kesler, E.M., Chander, P.T. and Branding, A.E. (1967) Dry molasses product using waste paper as a base for a possible feed for cattle. J. Dairy Sci., 50: 1994-1995.

6. Marshal, S.P. (1972) Sugarcane bagasse pellets and cotton seed hulls as roughage sources in complete rations. J. Dairy Sci., 55: 398

7. Kirubanath, K., Reddy, D.N. and Nagalakshmi, D. (2003) Effect of processing cotton straw based complete diet with expander-extruder on performance of crossbred calves. Asian-Australas J. Anim. Sci., 16(11): 1572-1576.

8. Nagalakshmi, D. and Reddy, D.N. (2011) On farm performance of lambs and buffaloes fed expander extruder processed cotton stalks based complete diets. Indian J. Anim. Nutr., 28(3): 253-258.

9. Mudgal, V., Mehta, M.K. and Rane, A.S. (2012) Effect of feeding lentil (Lens culinaris) straw based rations on nutrient utilisation, rumen fermentation, growth and economics in Barbari kids. Indian J. Small Rumin., 18(1): 80-84.

10. Mudgal, V., Mehta, M.K. and Rane, A.K. (2014) Utilization of ammoniated lentil (Lens culinaris) straw in the ration of growing Barbari kids. Indian J. Anim. Nutr., 31(4): 340-344.

11. Sharma, V., Purohit, G.R., Arya, R.S. and Harsh, M. (2006) Evaluation of some complete rations in sheep incorporating unconventional feed resources of arid zone of India. Anim. Nutr. Feed Technol., 6: 135-141.

12. Waje, S.H., Singh, S.S. and Mudgal, V. (2010) Effect of using forest grass based complete rations on growth and nutrient utilization in growing crossbred calves. Anim. Nutr. Feed Technol., 10: 229-234.

13. Anandan, S., Zoltan, H., Khan, A.A., Ravi, D. and Blummel, M. (2012) Feeding value of sweet sorghum bagasse and leaf residues after juice extraction for bio-ethanol production fed to sheep as complete rations in diverse physical forms. Anim. Feed Sci. Technol., 175: 131-136.

14. Seshaiah, C.V., Reddy, Y.R., Nagalakshmi, D. and Rao, S.J. (2012) Effect of feeding processed sweet sorghum (Sorghum bicolour (L.) Moench) based complete ration on the performance of buffalo calves. Indian J. Anim. Nutr., 29(2): 127-131

15. Babu, A.S., Rao, D.S., Reddy, Y.R. and Nagalakshmi, D. (2013) Effect of feeding various roughage based processed complete diets on intake and nutrient utilization in ram lambs. Indian J. Anim. Nutr., 30(3): 252-255.

16. Malisetty, V., Reddy, Y.R., Nagalakshmi, D., Mallam, M., Cherala, H.K., Reddy, R.A. and Manthani, G.P. (2013) Effect of feeding maize silage supplemented with concentrate and legume hay on growth in Nellore ram lambs. Vet. World, 6(4): 209-213.

17. Seshaiah, C.V., Rao, S.J., Reddy, Y.R., Nagalakshmi, D., Mahender, M. and Harikrishna, C. (2013) Effect of feeding processed sweet sorghum (Sorghum bicolour (L) Moench) crushed residue based complete ration on growth performance and feeding behavior of Murrah buffalo calves. Vet. World, 6(3): 151-155.

18. Kumari, N.N., Reddy, Y.R., Blummel, M., Nagalakshmi, D., Monika, T., Reddy, B.V.S. and Kumar, A.A. (2014) Effect of feeding differently processed sweet sorghum (Sorghum bicolor L. Moench) bagasse based complete diet on nutrient utilization and microbial $\mathrm{N}$ supply in growing ram lambs. Small Rumin. Res., 117: 52-57.

19. Afzal, Y., Ganai, A.M., Mattoo, F.A., Shad, F.I. (2009) Comparative dietary evaluation of oats straw and tree leaf based complete feed in block and mash form in sheep. Indian J. Small Rumin., 15: 212-216.

20. Jakhmola, R.C., Pahuja, T., Singh, N. and Raghuvansi, S.K.S. (2012) Effect of including the leaves of Calligonum polygonides or Acacia tortilis as a component in grass based complete diet on gas production and rumen fermentation. Indian J. Anim. Nutr., 29(1): 15-23.

21. Mishra, A.S., Tripathi, M.K., Vaithiyanathan, S. and Jakhmola, R.C. (2013) Nutritional evaluation of fallen tree leaves as source of roughage in complete feed blocks for sheep. Anim. Nutr. Feed Technol., 13: 223-234.

22. Ganai, A.M. and Beigh, Y.A. (2015) Effect of replacement 
of concentrate mixture in complete ration with graded levels of leaf meal on growth performance and nutrient utilization in sheep. Vet. Pract., 16(2): 304-307.

23. Senani, S., Sharath, B.S., Elangovan, A.V., Samanta, A.K. and Kolte, A.P. (2013) Use of spent maize cobs as source of roughage in the ration of Bandur lambs. Indian J. Anim. Sci., 83(11): 1207-1209.

24. Tiwari, R.K., Prasad, J., Garg, A.K. and Kumar, S. (2013) Influence of feeding urea ammoniated sugarcane bagasse pith on growth performance and nutrient utilization in crossbred bulls. Indian J. Anim. Sci., 83(2): 176-180.

25. Nagi, P.R.S., Reddy, D.N., Nagalakshmi, D., Reddy, Y.R. and Raghunandan, T. (2012) Effect of particle size of paddy straw on physical characteristics and performance of lambs fed paddy straw based complete diets. Anim. Nutr. Feed Technol., 12: 111-119.

26. Saijpaul, S., Chandrahas. and Saini, A.L. (2016) Effect of concentrate feed and crop residue based complete feed block on nutrient utilization, growth and physiological performance of Beetal kids under stall-fed conditions. Anim. Nutr. Feed Technol., 16: 71-81.

27. Singh, M.K., Tripathi, M.K., Dixit, A.K. and Singh, S.K. (2016) Effect of straw type (Cajnus cajan or Cicer arietinum) and form of diet on growth, feed efficiency and slaughter performance of weaned Jamunapari goat kids. Indian J. Anim. Sci., 86(3): 329-334.

28. Narasimha, J., Preetham, V.C. and Rao, S.T.V. (2013) Effect of feeding complete feed containing poultry litter on rumen nitrogen and total volatile fatty acids in sheep and goats. J. Res. ANGRAU, 41(2): 74-77.

29. Kushwaha, R. and Rai, S.N. (2011) Effect of feeding Acacia nilotica pods on feed intake, nutrient utilization and balances of $\mathrm{N}, \mathrm{Ca}$ and $\mathrm{P}$ in lactating goats. Indian J. Anim. Nutr., 28(3): 309-315.

30. Kushwaha, R., Rai, S.N. and Singh, A.K. (2012) Effect of feeding Acacia nilotica pods on body weight, milk yield and milk composition in lactating goats. Indian J. Anim. Res., 46(4): 366-370.

31. Kushwaha, R., Rai, S.N. and Singh, A.K. (2012) Influence of feeding Acacia nilotica pods on intake, nutrient utilization and immune status in pregnant goats. Indian J. Anim. Res., 46(1): 8-14.

32. Owaimer, A.N., Kraidees, M.S., Al-Saiady, M., Zahran, S. and Abouheif, M.A. (2004) Effect of feeding olive cake in complete diet on performance and nutrient utilization of lambs. Asian-Australas J. Anim. Sci., 17(4): 491-496.

33. Madhavi, K., Reddy, T.J., Reddy, Y.R. and Reddy, G.V.N. (2010) Growth rate and carcass characteristics of Nellore ram lambs fed on differently processed and detoxified neem (Azadirachta indica) seed cake incorporated complete diets. Anim. Nutr. Feed Technol., 10: 209-214.

34. Raj, D.N., Ramana, J.V., Rao, S.B.N., Kumar, D.D., Suryanarayana, M.V.A., Reddy, Y.R. and Prasad, K.S. (2016) Effect of incorporation of detoxified Karanja (Pongamia pinnata) and neem (Azadirachta indica) seed cakes in total mixed rations on milk yield, composition and efficiency in crossbred dairy cows. Indian J. Anim. Sci., 86(4): 489-492.

35. Goswami, A., Thakur, S.S. and Amrutkar, S.A. (2012) Growth and nutrient utilization in calves fed guar (Cyamopsis tetragonoloba) meal replacing groundnut cake in concentrate with and without added sweetener and flavour. Indian J. Anim. Nutr., 29(1): 40-45.

36. Sharma, S.L., Singh, P., Patil, A.K., Verma, A.K., Chaturvedi, V.B. and Kumar, S. (2012) Performance of crossbred calves fed on compressed complete feed block containing guar meal. Indian J. Anim. Nutr., 29(3): 231-234.

37. Chaturvedi, O.H., Kumar, S., Mishra, A.K., Arora, A.L. and Karim, S.A. (2009) Effect of complete feed or grazing and supplementation of lambs on performance, nutrient utilization and feed cost of production. Indian J. Anim. Sci., 79(9): 917-920
38. Chaturvedi, O.H., Bhatt, R.S. and Sahoo, A. (2014) Nutrient utilisation in grazing ewes supplemented with complete feed blocks during scarcity in semi-arid region. Indian $J$. Small Rumin., 20(1): 114-117.

39. Raghuvansi, S.K.S., Prasad, R., Tripathi, M.K., Mishra, A.S., Chaturvedi, O.H., Mishra, A.K., Saraswat, B.L. and Jakhmola, R.C. (2007) Effect of complete feed blocks or grazing and supplementation of lambs on performance, nutrient utilization, rumen fermentation and rumen microbial enzymes. Animal, 1(2): 221-226.

40. Sallam, S.M.A. (2005) Nutritive value assessment of the alternative feed resources by gas production and rumen fermentation in vitro. Res. J. Agric. Biol. Sci., 1: 200-209.

41. Makkar, H.P.S. (2004) Recent advances in the in vitro gas method for evaluation of nutritional quality of feed resources. In: Assessing the Quality and Safety of Animal Feeds. FAO Animal Production and Health Paper, ID 166954. FAO, Rome. p170. Available from: http://www. fao.org/docrep/007/y5159e/y5159e00.htm. Retrieved on 17-03-2012.

42. Mir, I.A., Kumar, R., Sharma, R.K. and Barman, K. (2010) Effect of herbs on in vitro digestibility of feed with rumen liquor of goat. Indian J. Vet. Res., 19: 13-18.

43. Ganai, A.M., Sharma, T. and Dhuria, R.K. (2011) Effect of Bhringraj (Eclipta alba) herb on in vitro fermentation characteristics of Bajra straw and Bajra straw-based. Appl. Biol. Res., 13(1): 38-42.

44. Ganai, A.M., Sharma, T. and Dhuria, R.K. (2015) Effect of yeast (Saccharomyces cerevisiae) supplementation on ruminal digestion of Bajra (Pennisetum glaucum) straw and Bajra straw-based complete feed in vitro. Anim. Nutr. Feed Technol., 15: 145-153.

45. Nehra, R., Sharma, T., Dhuria, R.K., Dangi, S.S. and Meel, M.S. (2013) Effect of supplementation of various levels of dewbean straw and Saccharomyces cerevisiae in complete feed on in vitro fermentation of goat rumen liquor. Indian J. Anim. Nutr., 30(2): 141-144.

46. Harikrishna, C., Mahender, M., Reddy, Y.R., Prakash, M.G., Sudhakar, K. and Pavani, M. (2012) Evaluation of in vitro gas production and nutrient digestibility of complete diets supplemented with different levels of thermotolerant yeast in Nellore rams. Vet. World, 5(8): 477-485.

47. Torres, N., Mendoza, G.D., Barcena, J.R., Gonzalez, S.S., Loera, O., Salem, A.Z.M. and Lara, A. (2013) Effect of a fibrolytic enzymatic extract from Cellulomonas flavigena on in vitro degradation and in vivo digestibility and productive performance of lambs. Anim. Nutr. Feed Technol., 13: 583-592.

48. Thakur, S.S. and Shelke, S.K. (2011) Effect of different periods of storage and heating temperatures of total mixed rations containing fibrolytic enzymes on enzyme activity and in vitro digestibility. Indian J. Anim. Nutr., 28(3): 293-298.

49. Grewal, R.S., Wadhwa, M. and Bakshi, M.P.S. (2012) Effect of metabolizable energy and rumen undegradable protein levels supplemented with or without vitamins on the in vitro fermentation of complete feeds. Indian J. Anim. Nutr., 29: 9-14.

50. Singh, A.P. and Srinivas, B. (2012) Associative effect of cereals and oil cakes in concentrate supplements and complete diet for ruminants on in vitro fermentation kinetics. Appl. Biol. Res., 14(2): 131-137.

51. Singh, T. (2014) Effect of Niacin Supplementation on Nitrogen Utilization from Different NPN Sources in Buffalo Calves. M.V.Sc. Thesis, Guru Angad Dev Veterinary and Animal Sciences University, Ludhiana-141004, Punjab, India.

52. Grewal, R.S., Wadhwa, M. and Bakshi, M.P.S. (2016) In vitro digestibility and fermentability of complete feeds as affected by vitamin supplementation. Indian J. Anim. Nutr., 33(3): 301-304.

53. Ramachandra, B., Nagabhushana, V., Thirumalesh, T. and 
Suresh, B.N. (2012) Evaluation of pulse by-products based complete diets for rumen degradation kinetics and microbial biomass synthesis by in vitro gas production technique. Indian J. Anim. Nutr., 29(2): 143-147.

54. Martz, F.A. and Belyea, R.L. (1986) Role of particle size and forage quality in digestion and passage by cattle and sheep. J. Dairy Sci., 69(7): 1996-2008.

55. Uden, P. (1988) The effect of grinding and pelleting hay on digestibility, fermentation rate, digesta passage and rumen and faecal particle size in cows. Anim. Feed Sci. Technol., 19(1-2): 145-157.

56. Reddy, G.V.N., Reddy, K.J. and Nagalakshmi, D. (2002) Effect of expander extruder processed complete diet containing sugarcane baggase on growth and nutrient utilization in Ongole bulls calves. Indian J. Anim. Sci., 72(5): 406-409.

57. Kishore, K.R., Ramana, J.V., Kumar, D.S., Ravi, A. and Rao, E.R. (2014) Effect of feeding crop residue-based complete rations on nutrient utilization in Nellore rams. Indian J. Small Rumin., 20(1): 37-40.

58. Sharma, D., Tiwari, D.P. and Mondal, B.C. (2010) Performance of crossbred female calves fed complete ration as mash or block vis-a-vis conventional ration. Indian $J$. Anim. Sci., 80(6): 556-560.

59. Datt, C., Reddy, G.V.N. and Kundu, S.S. (2011) Effect of feeding differently processed paddy straw based complete diets on feed intake and nutrient utilization in Nellore rams. Indian J. Anim. Nutr., 28(2): 160-165.

60. Phipps, R.H., Bines, J.A., Ful Ford, R.J. and Weeler, R.F. (1984) Complete diets for dairy cows, a comparison between complete diet and separate ingredients. J. Agric. Sci., 103: 171-180.

61. Singh, P.K., Chandramoni, C., Kumar, K. and Kumar, S. (2016) Effect of feeding wheat and rice straw based complete feed blocks on nutrients utilization, blood biochemical and growth performance in crossbred calves. Indian $J$. Anim. Sci., 86(7): 771-776.

62. Reddy, P.B., Reddy, T.J. and Reddy, Y.R. (2012) Growth and nutrient utilization in kids fed expander-extruded complete feed pellets containing red gram (Cajanus cajan) straw. Asian-Australas J. Anim. Sci., 25(12): 1721-1725.

63. Bhatia, T. (2004) Comparative Evaluation of Conventional and Complete Feed (Mash) Feeding System in Sheep. M.V.Sc. Thesis Submitted to Rajasthan Agricultural University, Bikaner.

64. Kumar, D., Datt, C., Das, L.K. and Kundu, S.S. (2013) Effect of different dietary protein levels on feed intake and blood parameters profile in growing Sahiwal calves. Indian J. Anim. Nutr., 30(4): 370-373.

65. Das, P.P., Roy, B. and Sardar, P. (2008) Evaluation of paddy straw based complete feeds through in vitro dry matter digestibility. Anim. Nutr. Feed Technol., 8: 127-132.

66. Pandya, P.R., Desai, M.C., Patel, G.R., Talpada, P.M., Pande, M.B. and Parnerkar, S. (2009) Economical rearing of crossbred calves on complete feeds, based on sugarcane bagasse and non-conventional feeds. Indian J. Anim. Nutr., 26(3): 211-215.

67. Tripathi, P., Dutta, T.K., Tripathi, M.K., Chaudhary, U.B. and Kumar, R. (2014) Preparation of complete feed pellet from monsoon herbages (Dactylotennium aegypticum, Cenchrus ciliaris and Tephrosia purpurea) and its utilisation in kids. Indian J. Small Rumin., 20(1): 31-36.

68. Ghosh, M.K. and Chatterjee, A. (2011) Nutrient digestibility and live weight change in yaks fed maize stover based complete feed block during winter. Indian J. Anim. Sci., 81(4): 427-428.

69. Khan, A.A., Sai, M., Rao, B., Ravi, D., Prasad, K.V.S., Anandan, S., Reddy, Y.R. and Blummel, M. (2016) Effect of varying the crop residue, cultivar and physical form on intake and nutrient utilization in Deccani sheep fed complete diets. Anim. Nutr. Feed Technol., 16: 197-208.

70. Nagalakshmi, D. and Reddy, D.N. (2012) Effect of feeding processed paddy straw based complete diets on nutrient utilization and rumen fermentation pattern in sheep. Indian $J$. Anim. Nutr., 29(2): 132-137.

71. Bhima, B., Reddy, Y.R., Reddy, M.S., Pawani, M. and Rao. L.V. (2014) Effect of thermo-tolerant yeast on intake and nutrient digestibility's in Murrah buffalo steers (Bubalus bubalis) fed straw based complete diet. Vet. World, 7(7): 501-504.

72. Nehra, R., Sharma, T., Dhuria, R.K. and Dangi, S.S. (2014) Effect of feeding green gram straw-based complete feed blocks with or without live yeast (Saccharomyces cerevisiae) supplementation in ration of goats. Anim. Nutr. Feed Technol., 14: 321-328.

73. Sehgal, J.P., Mir, I.A., Jha, P., Kumar, S. and Sharma, V.K. (2012) Effect of feeding fungal zoospores of Orpinomyces joyonii in TMR on nutrient utilization and rumen fermentation parameters in Murrah buffaloes. Indian J. Anim. Nutr., 29(1): 63-68.

74. Kumar, P.S., Tomer, S.K. and Sengar, S.S. (2000) Effect of wheat straw based complete diets on feed intake and nutrient utilization in buffaloes. Indian J. Anim. Nutr., 17: 341-343.

75. Prasad, J.R., Rao, Z.P. and Rao, D.S. (2000) Evaluation of complete rations containing groundnut haulms at different levels in sheep. Indian J. Anim. Nutr., 17(2): 147-152.

76. Singh, N.P. and Sankhyan, S.K. (2003) Effect of supplementary concentrate on growth, wool yield and quality in fine wool sheep. Anim. Nutr. Feed Technol., 3(2): 189-193.

77. Dhuria, R.K., Purohit, G.R. and Sharma, T. (2007) Effect of incorporation of mustard (Brassica campestris) straw in the complete feed on nutrient utilization by sheep. Anim. Nutr. Feed Technol., 7: 205-212.

78. Babu, J., Kumari, N.N., Reddy, Y.R., Raghunandan, T. and Sridhar, K. (2014) Effect of feeding sweet sorghum stover based complete ration on nutrient utilization in Nellore lambs. Vet. World, 7(11): 970-975.

79. Nagalakshmi, D., Reddy, D.N. and Prasad, M.R. (2014) Effect of feeding red gram stalks based complete diets on nutrient utilization and plane of nutrition in buffaloes. Indian J. Anim. Res., 48(3): 231-235.

80. Rajamma, K., Kumar, D.S., Rao, E.R. and Nath, D.N. (2014) Nutrient utilisation in buffalo bulls fed total mixed rations supplemented with exogenous fibrolytic enzymes. Indian J. Anim. Nutr., 31(3): 213-217.

81. Veerannapet, V., Malisetty, V. and Repalle, P.K. (2016) Effect of feeding maize stover-based complete rations on nutrient utilization, nutritive value and nitrogen balance in Nellore×Deccani male lambs. Indian J. Small Rumin., 22(1): 118-120.

82. Sinha, S.K., Chaturvedi, V.B., Singh, P., Verma, A.K. and Shivani, S. (2016) Evaluation of total mixed rations in terms of nutrient utilisation, methane production and gaseous exchange in cattle and buffaloes. Indian J. Anim. Nutr. 33(1): 33-38.

83. Samanta, A.K., Singh, K.K., Das, M.M., Maity, S.B. and Kundu, S.S. (2003) Effect of complete feed block on nutrient utilization and rumen fermentation in Barbari goats. Small Rumin. Res., 48: 95-102.

84. Bhatta, R., Vaithiyanathan, S., Singh, N.P. and Verma, D.L. (2007) Effect of feeding complete diets containing graded levels of Prosopis cineraria leaves on feed intake, nutrient utilization and rumen fermentation in lambs and kids. Small Rumin. Res., 67: 75-83.

85. Bartley, E.E. (1973) Effect of a self pelleted mixture of hay and calf starter on the performance of young dairy cows. J. Dairy Sci., 56: 817-820.

86. Florek, S. and Lewicki, C. (1982) Silage and supplementary mixture compared with complete feed in the fattening of bulls. Nutr. Abstr. Rev., 52: 11.

87. Bonsi, M.L.K., Osuji, P.O., Nshalai, I.V. and Taush, A.K. (1994) Graded level of Sesbania sesban and Leuceana leucocephala as supplements of teff straw given to Ethiopian Menz sheep. Anim. Prod., 59: 235-244. 
88. ICAR. (1985) Nutrient Requirement of Livestock and Poultry. Publications and Information Division, Indian Council of Agricultural Research, New Delhi.

89. Rajmane, S.M. and Deshmukh, S.V. (2000) Nutritional evaluation of complete rations in goats. Indian J. Anim. Nutr., 17(3): 246-248.

90. Venkateswarlu, M., Reddy, Y.R. and Reddy, M.S. (2013) Effect of feeding crop residues based complete rations on growth in ram lambs. Int. J. Sci. Environ. Technol., 2(1): 15-19.

91. Devasena, B. and Prasad, J.R. (2014) Performance of goats fed crop residue based complete rations. Haryana Vet., 53(1): 68-71.

92. Jafur, M.A., Ferdaus, M., Rashid, A., Khan, M.J., Monir, M.M. and Kawsar, M.H. (2015) Performance of growing Black Bengal goats as affected by different levels of crude protein in complete pellet diets. Indian J. Anim. Nutr., 32(3): 269-273.

93. Nagpal, A.K. and Singh, S. (2015) Performance of male camel calves fed on pelleted rations with two levels of protein. Indian J. Anim. Nutr., 32(4): 393-397.

94. Matto, F.A. and Ganai, A.M. (2006) Nutritive evaluation of total mixed rations containing rice straw and tree leaves in sheep. In: Proceedings of $\mathrm{VI}^{\text {th }}$ Animal Nutrition Association Biennial Conference Held at SKUAST-J, 15-17 $7^{\text {th }}$ September; 2006. p. 19-20.

95. Venkateswarlu, M., Reddy, Y.R., Nagalakshmi, D. and Mahender, M. (2014) Effect of feeding sorghum straw based complete rations with different roughage to concentrate ratio on growth and carcass characteristics in Nellore ram lambs. Anim. Nutr. Feed Technol., 14: 563-572.

96. Dhore, R.N., Deshmukh, G.B. and Dhok, A.P. (2014) Performance of goats on wheat and sorghum straw-based complete feed pellets. Indian J. Small Rumin., 20(1): 41-44.

97. Venkateshwarlu, V., Venkateswarlu, M., Reddy, Y.R. and Harikrishna, C. (2014) Effect of feeding maize stover based complete rations on growth and carcass characteristics in Nellore $\times$ Deccani ram lambs. Indian J. Anim. Nutr., 31(1): 36-43.

98. Pannu, M.S., Kaushal, J.R., Wadhwa, M. and Bakshi, M.P.S. (2002) Effect of naturally fermented wheat straw based complete feeds on the growth of buffalo calves. AsianAustralas J. Anim. Sci., 15(11): 1568-1572.

99. Rekhate, D.H., Madavi, V.B. and Dhok, A.P. (2007) Performance of goats fed arhar (Cajanus cajan) straw based pelleted complete ration. Anim. Nutr. Feed Technol., 7: 47-52.

100. Ananth, D. and James, C.S. (2013) Performance evaluation of cassava hay based complete pelleted ration on growing Malabari kids. Indian J. Anim. Nutr., 30(4): 358-364.

101. Radhakrishnan, L. and Balakrishnan, V. (2013) Effect of including Azadirachta indica (neem) leaves for replacing groundnut haulms in complete diets on growth of kids. Indian J. Small Rumin., 19(2): 159-161.

102. Medhi, D., Hanah, S.S., Sarmah, P.P., Tsering, K., Ali, E., Das, P.P., Das, P.J. and Deb, S.M. (2016) Performances of lactating yaks on silage and complete feed block based feeding regiments. Indian J. Anim. Sci., 86(2): 203-205.

103. Nagpal, A.K. (2013) Evaluation of roughage based complete feed pellet diets in male camel calves. Indian J. Anim. Nutr., 30(2): 169-174.

104. Emmanuel, N., Patil, N.V., Bhagwat, R.S., Lateef, A., $\mathrm{Xu}, \mathrm{K}$. and Liu, H. (2015) Effects of different levels of urea supplementation on nutrient intake and growth performance in growing camels fed roughage based complete pellet diets. Anim. Nutr., 1: 356-361.

105. Kumar, S., Sehgal, J.P., Puniya, A.K. and Kumari, R. (2015) Growth performance and fibre utilization of Murrah male buffalo calves fed wheat straw based complete feed blocks incorporated with superior anaerobic fungal zoospores (Neocallimastix sp. GR-1). Indian J. Anim. Sci., 85(3): 275-281.
106. Olson, H.H. (I965) What Do We Know About Complete Feeds for Dairy Cattle? Cornell Nutrition Conference and Feed Manufacturing. p80.

107. Reddy, G.V.N., Wilhelina, P.O. and Reddy, M.S. (2003) Effect of differently processed complete diet on performance of Murrah buffaloes. Indian J. Anim. Nutr., 20: 131-135.

108. Dougherty, D. (2002) Effect of Feeding Strategies on Milk. Pine Creek Nutrition Service, a California Corporation. Available from: http://www.moomilk.com/archive/nutrition-05.htm. Accessed on 10-05-2016.

109. Reddy, D.N. and Reddy, M.R. (1983) The effect of feeding complete feeds on nutrient utilization and milk production on crossbred cows. Indian J. Dairy Sci., 36: 421-423.

110. Holter, J.B., Urban, W.E., Hayes, H.H.J. and Davis, H.A. (1977) Utilization of diet components fed blended or separately to lactating cows. J. Dairy Sci., 60: 1288-1293.

111. Das, M.M., Singh, K.K., Samanta, A.K., Kundu, S.S. and Sharma, S.D. (2004) Effect of complete feed blocks on milk yield and its composition in buffalo. In: Proceedings of XI Animal Nutrition Conference, Jabalpur, 5-7 $7^{\text {th }}$ January. p78.

112. Rakes, A.H. (1969) Complete rations for dairy cattle. J. Dairy Sci., 52: 870.

113. Kumar, V., Tyagi, A.K., Thakur, S.S., Kundu, S.S. and Kale, V.R. (2014) Effect of feeding total mixed ration on productive performance and blood biochemical profile in lactating Murrah buffaloes. Indian J. Anim. Nutr., 31(4): 329-332.

114. Villavicencio, E., Rusoff, I.L., Girouard, R.E. and Waters, W.H. (1968) Comparison of complete feed rations to a conventional ration for lactating cows. J. Dairy Sci., 51: $1633-1638$.

115. O’Neil, B.F., Deighton, M.H., O'Loughlin, B.M., Mulligan, F.J., Boland, T.M., O’Donovan, M. and Lewis, E. (2011) Effect of a perennial ryegrass diet or total mixed ration diet offered to spring-calving HF dairy cows on methane emissions, dry matter intake and milk production. J. Dairy Sci., 94(4): 1941-1951.

116. Emery, R.S., Brown, L.D. and Thomas, J.W. (1964) Comparison of corncobs and hay in ground, restricted roughage rations affecting milk composition. J. Dairy Sci., 17: 1322 .

117. Leighton, R.E. and Rupell, W. (1964) Comparison of the feeding values of various low roughage rations and a normal ration for dairy cows. J. Dairy Sci., 47: 708.

118. Benz, J.J., Olson, H.H. and Alex, R. (1966) Source and level of roughages in dairy complete feeds. J. Anim. Sci., 25: 897.

119. Nelson, B.O., Elley, H.O. and Morgan, E.B. (1968) Effect of feeding varying forage to concentrate ratio to lactating dairy cows. J. Dairy Sci., 51: 626.

120. Owen, J.B., Miller, E.L. and Bridge, P.S. (1969) Complete diets given $a d$ lib to dairy cows. The effect of the level of inclusion of milled straw. J. Agric. Sci. Camb., 72: 351-357.

121. Owen, J.B. and Miller, E.L. (1971) Complete diets given $a d$ lib to dairy cows: The effect of straw content and cubing the diet. J. Agric. Sci., 77: 195.

122. Gupta, R.B., Tiwari, D.P. and Kumar, A. (2006) Effect of feeding complete ration vis-a-vis conventional ration on nutrient utilization and rumen metabolism in crossbred cattle. Indian J. Anim. Sci., 76(1): 55-60.

123. Huyen, N.T., Wanapat, M. and Navanukraw, C. (2012) Effect of mulberry leaf pellet (MUP) supplementation on rumen fermentation and nutrient digestibility in beef cattle fed on rice straw-based diets. Anim. Feed Sci. Technol., 175: 8-15.

124. Dhuria, R.K. and Sharma, T. (2010) Nutrient utilization of Bajra straw based complete feed in Magra lambs. Indian Vet. J., 87: 1115-1117.

125. Dhuria, R.K., Sharma, T. and Purohit, G.R. (2011) Effect of densification of gram straw based complete feed on rumen and haemato biochemical parameters in Magra lambs. Anim. Nutr. Feed Technol., 11: 133-140. 
126. Dhuria, R.K., Sharma, T. and Garg, D.D. (2011) Mustard straw based complete feed blocks for lambs. Indian Vet. J., 11(1): 47-49.

127. Garg, D.D., Sharma, T. and Dhuria, R.K. (2009) Evaluation of groundnut straw based complete feed blocks alone and in combination with yeast in ration of sheep. Anim. Nutr. Feed Technol., 9: 137-144.

128. Jha, P., Sehgal, J.P., Lather, P., Sharma, V.K. and Jha, N. (2011) Effects of supplementation of wheat straw based complete feed blocks with fungal zoospores and sulphur on rumen fermentation in buffalo calves. Indian J. Anim. Nutr., 28(2): 144-148.

129. Ankuo, S. and Chuen, R.H. (1999) Effects of feeding total mixed ration on the lactational performance and blood parameters of dairy goat. J. Taiwan Livest. Res., 32: 183.

130. Delany, K.K., Macmillan, K.L., Grainger, C., Thomson, P.C., Blache, D., Nicholas, K.R. and Auldist, M.J. (2010) Blood plasma concentrations of metabolic hormones and glucose during extended lactation in grazing cows or cows fed a total mixed ration. J. Dairy Sci., 93(12): 5913-5920.

131. Nagpal, A.K., Roy, A.K. and Arora, M. (2002) Nutrient utilization of guar (Cymopsistetra gonoloba) phalgati based complete diet in camel calves. Indian J. Anim. Nutr., 19(2): 149-152.

132. Rekhate, D.H., Patil, J.M. and Dhok, A.P. (2008) Effect of pelleted complete diet on blood biochemical profile of goats. Indian J. Anim. Res., 42(3): 227-229.

133. Beigh, Y.A. and Ganai, A.M. (2014). Effect of feeding graded levels of leaf meal on digestibility, clinical chemistry and rumen fermentation of lambs. Anim. Nutr. Feed Tech., 13: 549-562.

134. Ramulu, S.P., Nagalakshmi, D. and Kumar, M.K. (2015) Effect of zinc supplementation on haematology and serum biochemical constituents in Murrah buffalo calves. Indian J. Anim. Res., 49(4): 482-486.

$* * * * * * * *$ 